\title{
TIME SCALES IN THE EVOLUTION OF SOLUTION POROSITY IN POROUS COASTAL CARBONATE AQUIFERS BY MIXING CORRO- SION IN THE SALTWATER-FRESHWATER TRANSITION ZONE.
}

\author{
ČASOVNO MERILO RAZVOJA POROZNOSTI ZARADI KOROZIJE \\ MEŠANICE V MEJNEM OBMOČJU SLADKOVODNIH LEČ \\ V MEDZRNSKO POROZNEM KARBONATNEM OBALNEM \\ VODONOSNIKU
}

\author{
Wolfgang DREYBRODT ${ }^{1} \&$ Douchko ROMANOV ${ }^{2}$
}

\begin{abstract}
UDC 556.3:552.54:539.217

Wolfgang Dreybrodt and Douchko Romanov: Time scales in the evolution of solution porosity in porous coastal carbonate aquifers by mixing corrosion in the saltwater-freshwater transition zone.

Dissolution of calcium carbonate in the saltwater-freshwater mixing zone of coastal carbonate aquifers up to now has been treated by coupling geochemical equilibrium codes to a reactivetransport model. The result is a complex nonlinear coupled set of differential transport-advection equations, which need high computational efforts. However, if dissolution rates of calcite are sufficiently fast, such that one can assume the solution to be in equilibrium with respect to calcite a highly simplified modelling approach can be used. To calculate initial changes of porosity in the rock matrix one only needs to solve the advection-transport equation for salinity $s$ in the freshwater lens and its transition zone below the island. Current codes on density driven flow such as SEAWAT can be used. To obtain the dissolution capacity of the mixed saltwater-freshwater solutions the calcium equilibrium concentration $\mathrm{c}_{\mathrm{eq}}(\mathrm{s})$ is obtained as a function of salinity by PHREEQC-2. Initial porosity changes can then be calculated by a simple analytical expression of the gradient of the spatial distribution $\mathrm{s}(\mathrm{x}, \mathrm{y})$ of salinity, the distribution of flow fluxes $\mathrm{q}(\mathrm{x}, \mathrm{y})$ and the second derivative of the calcium equilibrium concentration $\mathrm{c}_{\mathrm{eq}}(\mathrm{s})$ with respect to salinity s.

This modelling approach is employed to porosity evolution in homogeneous and heterogeneous carbonate islands and coastal aquifers. The geometrical patterns of porosity changes and the reasons of their origin will be discussed in detail. The results reveal initial changes of porosity in the order of several $10^{-6}$ per year. This places the time scale of cavern evolution to orders from several tens of thousands to a hundred thousand years.

Keywords: Calcite dissolution, mixing corrosion, saltwaterfreshwater, mixing zone, coastal aquifer, evolution of porosity.
\end{abstract}

Izvleček

UDK 556.3:552.54:539.217

Wolfgang Dreybrodt and Douchko Romanov: Časovno merilo razvoja poroznosti zaradi korozije mešanice $v$ mejnem območju sladkovodnih leč v medzrnsko poroznem karbonatnem obalnem vodonosniku

Dosedanji modeli raztapljanja kalcijevega karbonata v območju mešanja sladke in slane vode temeljijo na združitvi geokemičnih ravnotežnih in reakcijsko transportnih modelov. Dobljeni sistem nelinearnih enačb zahteva veliko računske moči. Če je hitrost raztapljanja dovolj visoka in lahko predpostavimo, da je raztopina ves čas $\mathrm{v}$ ravnotežju glede na kalcit, rešimo problem $\mathrm{z}$ poenostavljenim modelskim pristopom. Začetno spreminjanje poroznosti $\mathrm{v}$ kamninski matriki določa advekcijsko tranportna enačbo, ki opisuje slanost v sladkovodni leči in prehodnem območju pod njo. Pri reševanju porabimo dostopne programske kode. Tokove nastale zaradi razlik v gostoti modeliramo s programom SEAWAT, topnost kalcita $v$ mešanici sladke in slane vode $\mathrm{v}$ odvisnosti od slanosti pa izračunamo s programom PHREEQC-2. Začetno spreminjanje poroznosti lahko nato izračunamo $\mathrm{z}$ enostavnim analitičnim izrazom gradienta prostorske razporeditve slanosti $\mathrm{s}(\mathrm{x}, \mathrm{y})$, razporeditve gostot toka $\mathrm{q}(\mathrm{x}, \mathrm{y})$ in drugega odvoda ravnotežne koncentracije kalcija po slanosti.

Tak modelski pristop uporabimo pri računanju razvoja poroznosti $\mathrm{v}$ homogenih in heterogenih karbonatnih otokih in obalnih vodonosnikih. Podrobno so prikazani vzroki in geometrijski vzorci spreminjanja poroznosti. Rezultati kažejo, da je začetna hitrost spremembe poroznosti reda velikosti $10^{-6}$ na leto. To postavi časovno merilo razvoja jam v območje nekaj deset tisoč do sto tisoč let.

Ključne besede: Raztapljanje kalcita, korozija mešanice, območje mešanja sladke in slane vode, obalni vodonosnik, razvoj poroznosti.

\footnotetext{
${ }^{1}$ Universitaet Bremen, FB1, Karst Processes Research Group, Bremen, Germany, e-mail: dreybrodt@ifp.uni-bremen.de

${ }^{2}$ Freie Universitaet Berlin, Fachbereich Geowissenschaften, Berlin, Germany, e-mail: dromanov@zedat.fu-berlin.de

Received/Prejeto: 21.12.2006
} 


\section{INTRODUCTION}

Carbonate islands consisting of porous rocks show typical karst features characterized by large dissolution chambers close to the coast, which have been created by mixing corrosion in the fresh-saltwater transition zone (Mylroie and Carew, 2000). Figure1 represents the basic concept. Due to meteoric precipitation a freshwater lens

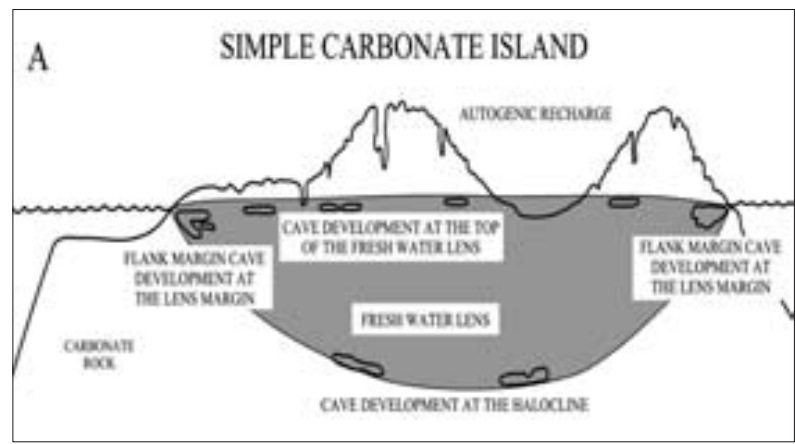

Fig. 1: Conceptual representation of a carbonate island from Mylroie and Carew (2000).

builds up, floating on the denser saltwater (Vacher, 1988) The transition from freshwater to seawater is not sharp. Depending on many factors, such as tidal pumping, periodicity of annual recharge, and the heterogeneity of the rock's properties in the aquifer it exhibits a transition zone. This zone can range from a few meters to half the depth of the lens. In this zone mixing between saltwater and freshwater activates mixing corrosion, which creates large chambers. These are called flank-margin caves. Figure 2 shows such a cave with its typical solutional features on its ceiling.

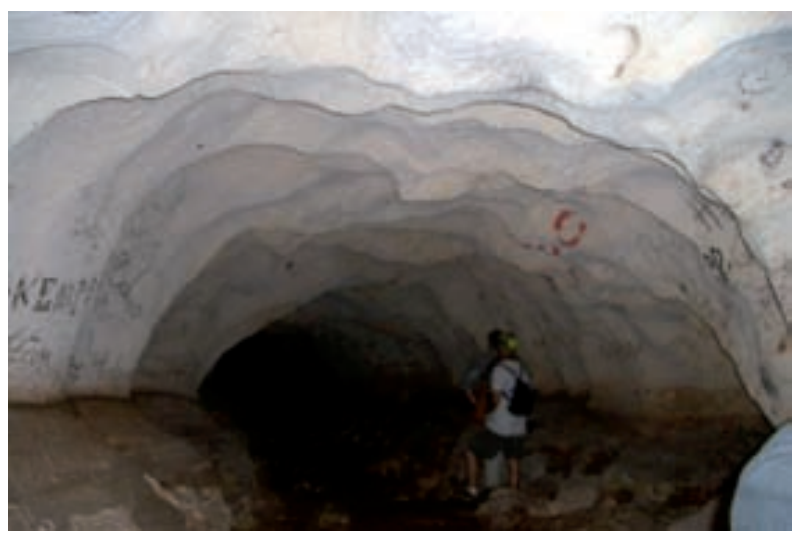

Fig. 2: Flank-margin cave.

When seawater mixes with a solution of $\mathrm{H}_{2} \mathrm{O}-\mathrm{CO}_{2}-$ $\mathrm{CaCO}_{3}$ saturated with respect to $\mathrm{CaCO}_{3}$ the mixture is no longer in equilibrium with respect to calcite. Depending on the chlorine concentration s, termed as chlorinity further on, of the mixture undersaturation or supersaturation may result. Figure 3 gives an example. It depicts the difference

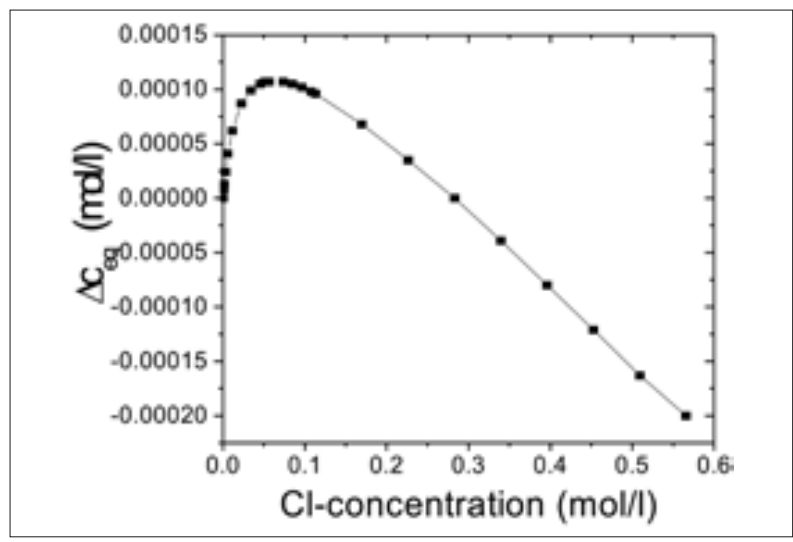

Fig. 3: $\Delta c_{e q}(s)=c_{e q}(s)-c_{\text {mix }}(s)$ as a function of chlorine concentration. The curve extends from pure freshwater (right) to pure seawater (left).

$\Delta c_{e q}(s)=c_{e q}(s)-c_{m i x}(s)$ of the calcium concentration $c_{\text {mix }}(s)$ of the mixture and that of its corresponding equilibrium concentration $c_{e q}(s)$ as a function of s. This is the amount of calcium, which can be dissolved or precipitated, when the mixed solution is in contact with carbonate rock. The $\mathrm{H}_{2} \mathrm{O}-\mathrm{CaCO}_{3}-\mathrm{CO}_{2}$ solution used to calculate this data is in equilibrium with a partial pressure of $\mathrm{CO}_{2}$ of 0.01 atm at a temperature of $20^{\circ} \mathrm{C}$. The seawater also is at $20^{\circ} \mathrm{C}$. The data in Fig. 3 were obtained by use of the code PHREEQC-2 (Parkhurst and Apello, 1999 ).

From Figure 3 it is evident that mixtures with low content of seawater, chlorinity $\mathrm{s} \leq 0.3 \mathrm{~mol} / \ell$, can dissolve calcite, whereas mixtures with higher chlorinity may precipitate calcite. Renewed aggressivity due to mixing therefore occurs only at the freshwater side of the mixing zone where chlorinity is low. If one assumes that dissolution of calcite proceeds sufficiently fast the solution there will be saturated with respect to calcite.

Dissolution of minerals under such conditions is termed a gradient reaction (Phillips, 1991). Here we use this as a novel instrument to explain the evolution of porosity in carbonate islands. Dissolution rates of limestone are sufficiently fast, such that after mixing between saltwater and freshwater we assume saturation with respect to calcite in the entire lens.

After attaining equilibrium the local distribution of calcium concentration $\mathrm{c}_{\mathrm{eq}}(\mathrm{s}(\mathrm{x}, \mathrm{z}))$ becomes stationary and exhibits gradients. Necessarily advection and diffusion must transport the dissolved limestone to the outflow of the aquifer. 


\section{DISSOLUTION IN THE MIXING ZONE}

\section{The advection term:}

In Figure 4 we consider a volume element dxdydz at position $(\mathrm{x}, \mathrm{y}, \mathrm{z})$, into which flow, with components $\mathrm{q}_{\mathrm{x}}$ and $\mathrm{q}_{\mathrm{z}}$, enters perpendicular to dydz or dxdy. The flux $\mathrm{q}$ is defined by the volume of fluid per time unit entering through a unit of surface area and is given in $\left[\mathrm{cm}^{3} /\left(\mathrm{cm}^{2} \mathrm{~s}\right)=\mathrm{cms}^{-1}\right]$.
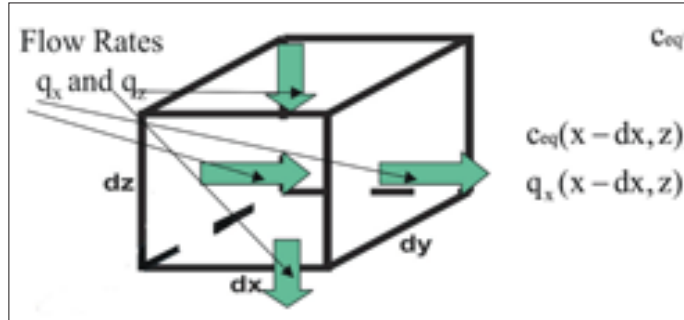

$$
\mathrm{ces}_{\mathrm{eq}}(\mathrm{x}, \mathrm{z}-\mathrm{dz}), \mathrm{q}_{\mathrm{z}}(\mathrm{x}, \mathrm{z}-\mathrm{dz})
$$

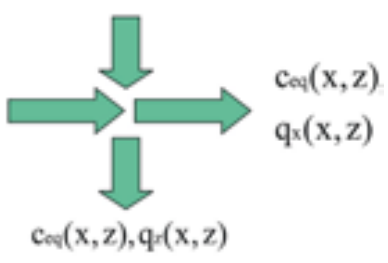

Fig. 4: Mass balance for the advection term.

The component $q_{x}$ transports solution from the neighbouring elementary cell at position $(\mathrm{x}-\mathrm{dx}, \mathrm{y}, \mathrm{z})$ via the area dydz into the cell dxdydz. This solution has already attained equilibrium $\mathrm{c}_{\mathrm{eq}}(\mathrm{s}(\mathrm{x}-\mathrm{dx}, \mathrm{y}, \mathrm{z}))$ at position $\mathrm{x}-\mathrm{dx}$. When it enters into the volume element dxdydz it must dissolve or precipitate limestone to adjust its calcium concentration to equilibrium $\mathrm{c}_{\mathrm{eq}}(\mathrm{s}(\mathrm{x}, \mathrm{y}, \mathrm{z}))$ at position $\mathrm{x}$. On the other hand solution from the element dxdydz flows out into the neighbouring cell with flux $\mathrm{q}_{\mathrm{x}}(\mathrm{x}, \mathrm{y}, \mathrm{z})$. Mass conservation requires that the amount of limestone dissolved per time unit in the element dxdydz must be equal to the difference of mass transported into the cell and that transported out of it. From this one finds

$$
\frac{\left(q_{x}(x, z) \cdot c_{e q}(x, z)-q_{x}(x-d x, z) \cdot c_{e q}(x-d x, z)\right) d y d z}{d x d y d z}=Q_{x}
$$

An analogue equation exists for $Q_{z}$ the amount of limestone dissolved by the flux component $\mathrm{q}_{\mathrm{z}}$ entering via the surfaces $(\mathrm{dx}, \mathrm{dy})$.

$$
\frac{\left(q_{z}(x, z) \cdot c_{e q}(x, z)-q_{z}(x, z-d z) \cdot c_{e q}(x, z-d z)\right) d x d y}{d x d y d z}=Q_{z}
$$

Therefore

$Q_{a d v}=Q_{x}+Q_{z}=\vec{q} \cdot \operatorname{grad}\left(c_{e q}(s(x, z))+c_{e q}(s(x, z) \cdot \operatorname{div} \vec{q}\right.$

Because the flux q follows the Darcy law of incompressible fluids, $\operatorname{div}(\vec{q})=0$.

$Q_{a d v}=\vec{q} \cdot \operatorname{grad}\left(c_{m i x}+\Delta c_{e q}\right)$

whereby we have replaced $c_{e q}=c_{m i x}+\Delta c_{e q} \cdot c_{m i x}$ is the calcium concentration resulting from the mixing of seawater and freshwater and is a linear function of $\mathrm{Cl}$-concentration $\mathrm{s}$.

$$
c_{\text {mix }}=c_{\text {fresh }}+\left(c_{\text {sea }}-c_{\text {fresh }}\right) \cdot \frac{s}{s_{\text {sea }}}
$$

$\Delta c_{e q}$ is the increase of equilibrium concentration as given in Figure 3, $\mathrm{s}_{\text {sea }}$ is chlorinity of seawater.

\section{The diffusion term:}

Our mass balance so far, however, is incomplete because gradients of $\mathrm{C}_{\text {eq }}$ cause transport by diffusion. The rate $Q_{D}$ of mass transport by diffusion is given by

$Q_{D}=-\emptyset \cdot D \vec{\nabla}^{2}\left(c_{m i x}+\Delta c_{e q}\right)$

where $\mathrm{D}=\mathrm{qd} / \Phi+\mathrm{D}_{\mathrm{m}}$ is the coefficient of dispersion. $\Phi$ is the porosity of the rock and d its grain size. (Phillips, 1991). Dm is the constant of molecular diffusion $\left(10^{-5} \mathrm{~cm} \mathrm{~s}^{-1}\right)$.

\section{The total rate:}

The total dissolution rate $Q_{\text {tot }}$ is then given by $Q_{D}+Q_{a d v}$.

$Q_{t o t}=\vec{q} \operatorname{grad}\left(c_{m i x}\right)-\emptyset D \vec{\nabla}^{2}\left(c_{m i x}\right)+\vec{q} g r a d\left(\Delta c_{e q}\right)-\emptyset D \vec{\nabla}^{2}\left(\Delta c_{e q}\right)$

Due to the linearity of $\mathrm{c}_{\text {mix }}$ with salinity s (eqn. 5) one finds $\operatorname{grad}\left(\mathrm{c}_{\text {mix }}\right)$ proportional to $\operatorname{grad}(\mathrm{s})$.

The distribution of salinity is governed by the advection-diffusion equation

$\partial s / \partial t=\vec{q} \operatorname{grad} s-\Phi D(\vec{\nabla})^{2} s=0$,

because the distribution $s$ is stationary. From the linearity of $s$ with $c_{\text {mix }}$ we have

$\partial c_{m i x} / \partial t=\vec{q} g r a d c_{m i x}-\emptyset D(\vec{\nabla})^{2} c_{m i x}=0$,

The total dissolution rate $\mathrm{Q}_{\mathrm{tot}}$ is given by the master equation

$Q_{t o t}=\vec{q} \operatorname{grad}\left(\Delta c_{e q}\right)-\emptyset D \vec{\nabla}^{2}\left(\Delta c_{e q}\right)$

Since $\Delta \mathrm{c}_{\mathrm{eq}}(\mathrm{s}(\mathrm{x}, \mathrm{z}))$ is a function of local distribution $\mathrm{s}(\mathrm{x}, \mathrm{z})$ by differentiating and using the chain rule, one finds using equation 8

$Q_{t o t}=-\varnothing\left(\mathrm{qd} / \varnothing+\mathrm{D}_{\mathrm{m}}\right) \cdot(\vec{\nabla} s(x, z))^{2} \frac{\partial^{2} \Delta c_{e q}}{\partial s^{2}}$

This master equation relates the amount of dissolved material per unit volume of the rock matrix $\left[\mathrm{mol} \mathrm{cm}^{-3} \mathrm{~s}^{-1}\right]$ 
to the gradient of salinity s, to the second derivative of $c_{e q}(s)=c_{\text {mix }}(s)+\Delta c_{e q}(s)$, and the flux q. $\partial^{2} \Delta c_{e q} / \partial s^{2}$ can be obtained by differentiating twice the data set of Figure 3 . This data set was obtained by using the program PHREEQC2 and calculating about 50 closely spaced points to avoid numerical errors, when differentiating twice. The result is shown in Figure 5.

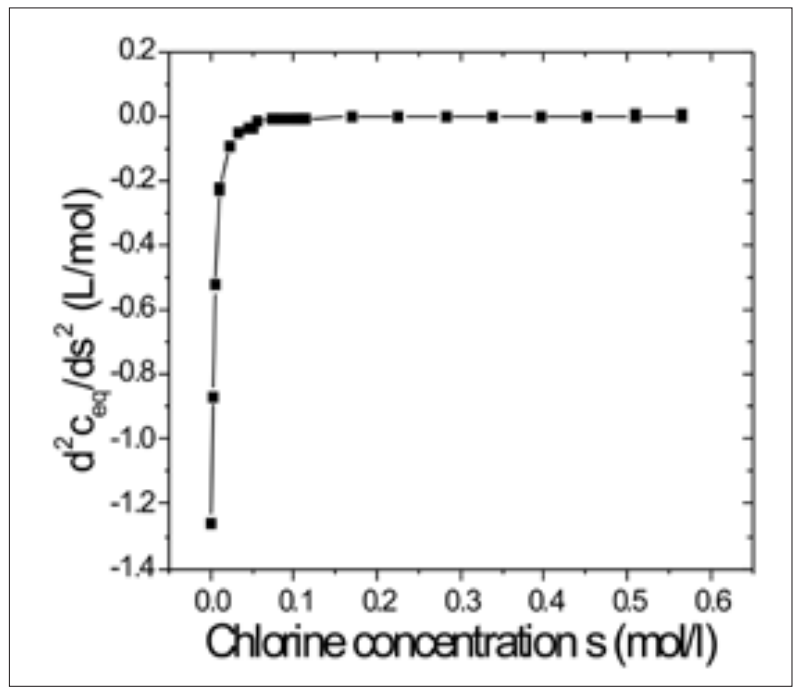

Fig. 5: Second derivative $\frac{\partial^{2} c_{e q}}{\partial s^{2}}$.
The function $|\Delta s(\vec{x})|^{2}$ and the flow distribution $|\vec{q}(x)|$ can be obtained by the numerical hydrologic model SEAWAT, as will be shown in the next sections. To calculate the initial change of porosity it is sufficient to obtain the flux and salinity distribution of an island without considering calcite dissolution, because the time to establish a stationary state of the lens is in the order of 100 years. It is a good approximation to assume that during this time the change of porosity is insignificant.

Equation. 11 can be written in terms of the change of porosity as

$$
\frac{\partial \phi}{\partial t}=\frac{M}{\rho} Q_{t o t}=-\emptyset D(\vec{\nabla} s(x, z))^{2} \frac{\partial^{2} \Delta c_{e q}}{\partial s^{2}} \frac{M}{\rho}
$$

$\mathrm{M}=100 \mathrm{~g} / \mathrm{mol}$ is the molecular weight at $\mathrm{CaCO}_{3}$, $\rho=2.7 \mathrm{~g} / \mathrm{cm}^{3}$ is the density of compact $\mathrm{CaCO}_{3} . \mathrm{Q}_{\text {tot }}$ the mass of $\mathrm{CaCO}_{3}$ dissolved per time from a unit volume of the rock matrix is given in mol s $\mathrm{cm}^{-3} . \partial \phi / \partial t$ is the amount of volume dissolved per time from a unit volume of the rock matrix $\left(\mathrm{cm}^{3} \mathrm{~s}^{-1} / \mathrm{cm}^{3}\right)$. By use of equation 12 it is now possible to construct a conceptual frame for the evolution of porosity. Tests of this approach on simple benchmark models have shown its reliability and have found agreement to experimental data (Romanov and Dreybrodt, 2006).

\section{INITIAL CHANGES OF POROSITY IN A HOMOGENEOUS ISLAND.}

To obtain the initial distributions of flux $\mathrm{q}$ and chlorinity $s$ in the lens of a carbonate island we have used SEAWAT by USGS (Guo and Langevin, 2002). The modeling domain is shown in Figure 6. The island is a strip of $1 \mathrm{~km}$

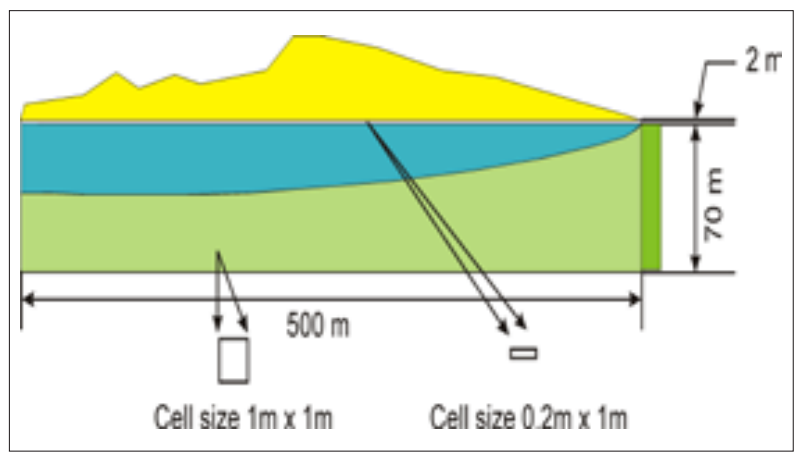

Fig. 6: Modeling domain of a carbonate island.

width. Porosity $\varnothing$ and the hydraulic conductivity K are uniform $(\varnothing=0.30, K=10 \mathrm{~m} /$ day $)$. The transversal dispersivity is $\mathrm{a}_{\mathrm{T}}=\mathrm{d}=0.01 \mathrm{~cm}$, the longitudinal dispersivity is $\mathrm{a}_{1}=0.1 \mathrm{~cm}$. Infiltration is $3 \cdot 10^{-3} \mathrm{~m} /$ day $=1.11 \mathrm{~m} /$ year. This way the maximal depth of the lens is about $50 \mathrm{~m}$ below sea level. The lower border of the domain reaches down to $70 \mathrm{~m}$. At that boundary an impermeable layer imposes no-flow conditions. The grid size in the domain is $1 \mathrm{mx}$ $1 \mathrm{~m}$ in the part below sea level. In the part above sea level $(2 \mathrm{~m})$ the grid size is $0.2 \mathrm{~m}$ by $1 \mathrm{~m}$. In its initial state when the island emerges out from the sea the entire aquifer is filled with seawater. When the island receives recharge from meteoric freshwater the lens builds up. A stable stationary lens is obtained after about 30 years. Fig. 7 shows the results of the model run.

Figure $7 \mathrm{a}$ shows the freshwater lens (white), the transition zone and its distribution of $\mathrm{Cl}$-concentration by a color code. From this distribution of chlorinity one can extract the scalar value $|\vec{\nabla} s(\vec{x})|^{2}$ and $\partial^{2} c_{e q}(s(\vec{x})) / \partial s^{2}$. Figure $7 \mathrm{~b}$ shows the chlorinity in units normalized to its maximum value along several horizontal sections as depicted in Figure $7 \mathrm{a}$. The lowest section at $-68 \mathrm{~m}$ is entirely in saltwater with maximum $\mathrm{Cl}$-concentration. The section at $-55 \mathrm{~m}$ extends through the almost horizontal base of 


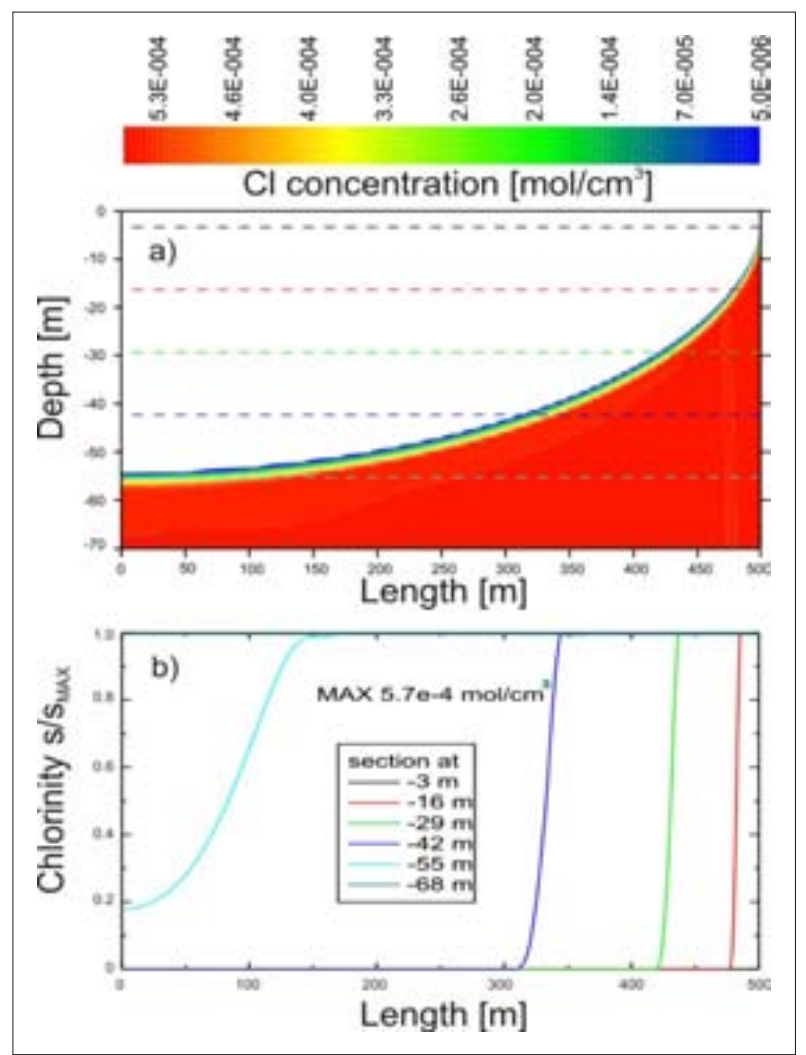

Fig. 7: Homogeneous island. a) Local distribution of chlorinity $s(\vec{x})$. The white region designates the freshwater lens. b) chlorinity along horizontal sections as indicated in a).

the lens and shows a wide zone where the concentration raises to that of seawater. The upper sections cut through the mixing zone and there the rise in concentration from freshwater to seawater becomes steeper.

The square of the gradient $|\vec{\nabla} s|^{2}$ is shown by Figures $8 \mathrm{a}, \mathrm{b}$ also normalized to its maximum value in Figure 8b. Figure 8a illustrates its local distribution, which exhibits large values only in the region of the transition zone. The horizontal distribution along horizontal sections is depicted in Figure $8 \mathrm{~b}$.

The second derivative $\partial^{2} c_{e q}(s(\vec{x})) / \partial s^{2}$ obtained from the Cl-concentration in Figure 7a is given in Figure 9a. Its distribution is limited to that part of the transition zone with $0<s<0.03$ mole/ $\ell$. See Figure 5 . This corresponds to a narrow fringe at the freshwater side of the transition zone with seawater content from zero up to about $4 \%$. In any case creation of porosity is possible only in this restricted region. Figure $9 \mathrm{~b}$ for completeness depicts some distributions of $\partial^{2} c_{e q}(s(\vec{x})) / \partial s^{2}$ along horizontal sections.

To calculate the initial rate of change in porosity (conf. eqn 12) the Darcy fluxes q must be known. They are also obtained from the model run and shown in Fig 10. The flux is low in the center of the island $q \leq 1 \mathrm{~m}$ /year), but increases by orders of magnitude when the fluid

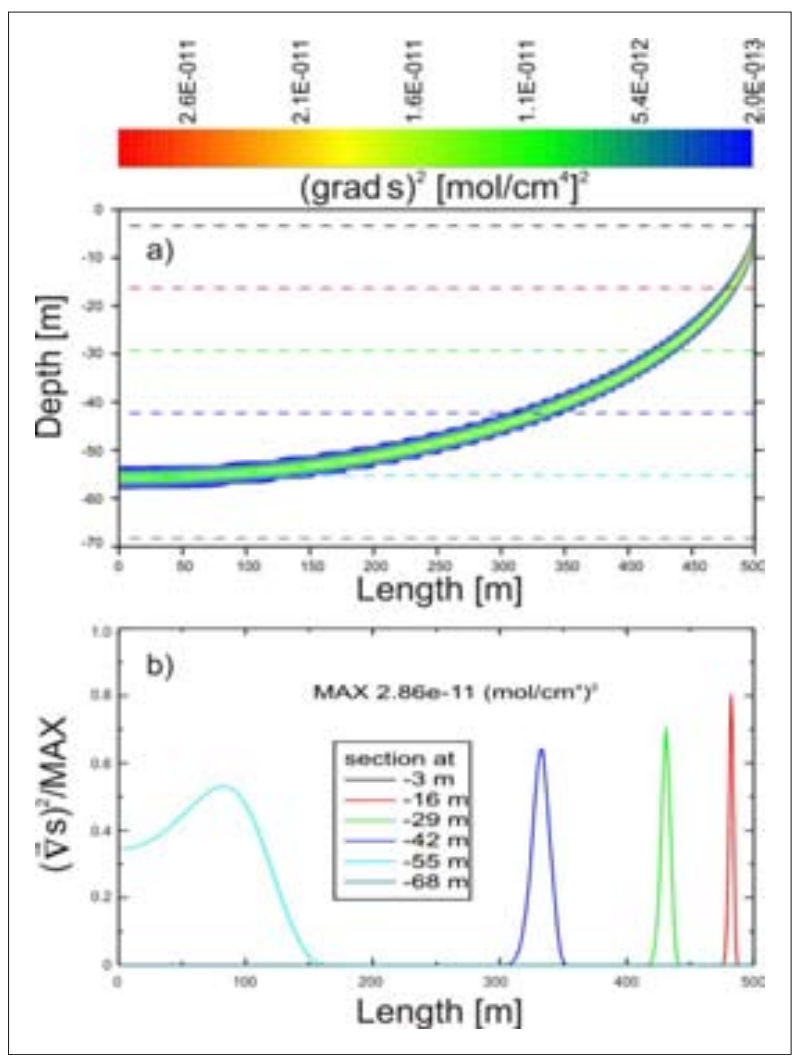

Fig. 8: Homogeneous island. a) Local distribution of the square of gradients $\left.|\vec{\nabla} s(\vec{x})|^{2}, b\right)$ square of gradients along horizontal sections as indicated in $a$ ).

moves coastward, where it becomes about $0.2 \mathrm{~m} /$ day at the outflow.

The dispersion coefficient $\mathrm{D}=\mathrm{qd} / \varnothing+\mathrm{D}_{\mathrm{m}}$ (conf. eqn. 11) depends on the flux q, but also on the coefficient of molecular diffusion $\mathrm{D}_{\mathrm{m}}=10^{-5} \mathrm{~cm}^{2} / \mathrm{s}$. For low flux $\mathrm{q}<10^{-4} \mathrm{cms}^{-1}$ and particle diameters $\mathrm{d} \leq 10^{-2} \mathrm{~cm}$ dispersion is dominated by molecular diffusion. In the following scenarios we have used $\mathrm{d}=10^{-2} \mathrm{~cm}$, a realistic value in porous limestone. Therefore in the range of flux, which can be read from Figure 10b the dispersion coefficient in the center of the island is $\mathrm{D}=10^{-5} \mathrm{~cm}^{2} \mathrm{~s}^{-1}$. It increases by about $60 \%$ of this value at the coast.

From the data given in Figures 7a, 8a, and 9a the initial porosity is obtained by use of eqn. 12. Figure 11 illustrates these results. Changes in porosity are restricted to a small fringe in the transition zone and are fairly even along it. They are in the order of $10^{-6}$ year $^{-1}$. This is sufficient to create substantial porosity within 100,000 years. At the outflow flank margin caves can develop in 10,000 years. One has to keep in mind, however, that the approximation as a homogeneous island is a high idealization. Any disturbances, which increase the width of the transition zone, will reduce the gradients of chlorinity and therefore on more realistic settings the initial porosity changes accordingly. 


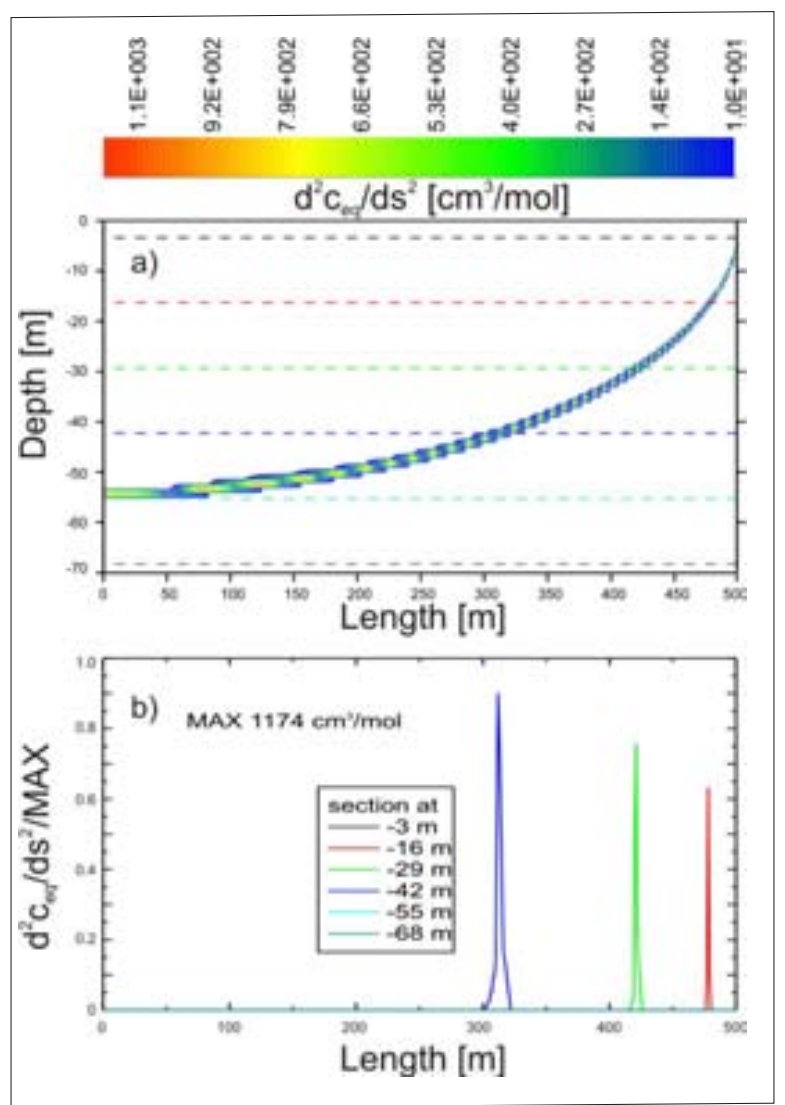

Fig. 9: Homogeneous island. Local distribution of the second derivative $\left.\frac{\partial^{2} c_{e q}}{\partial s^{2}}, b\right)$ second derivative along horizontal sections as indicated in a).

As we have stated already, the second derivative is restricted to narrow regions in the freshwater side of the transition zone. It exhibits significant values only at locations where the water contains between zero and $4 \%$ saltwater (see Figure 5). On the other hand the gradient in salinity is maximal at mixtures of about $50 \%$ seawater, because it arises from a diffusive process. In the region of maximal gradients, however, the second derivative is small. Vice versa in the region of high values of the second derivative, the gradients of salinity are low. This is illustrated in Figure 12. This figure is an overlay of the horizontal distributions (grads) ${ }^{2}$ in Figure 8b (red curves), the second derivative in Figure 9b (green curves), and the initial porosity change in Figure 11b (black curves). All curves are normalized to their individual maximum values. Therefore their values are not comparable in this figure. What can be compared, are the locations. Evidently the curves for gradients and second derivative are well separated. The curves of porosity change are proportional to the product of the square of the gradient and the second derivative. Porosity change displays high values

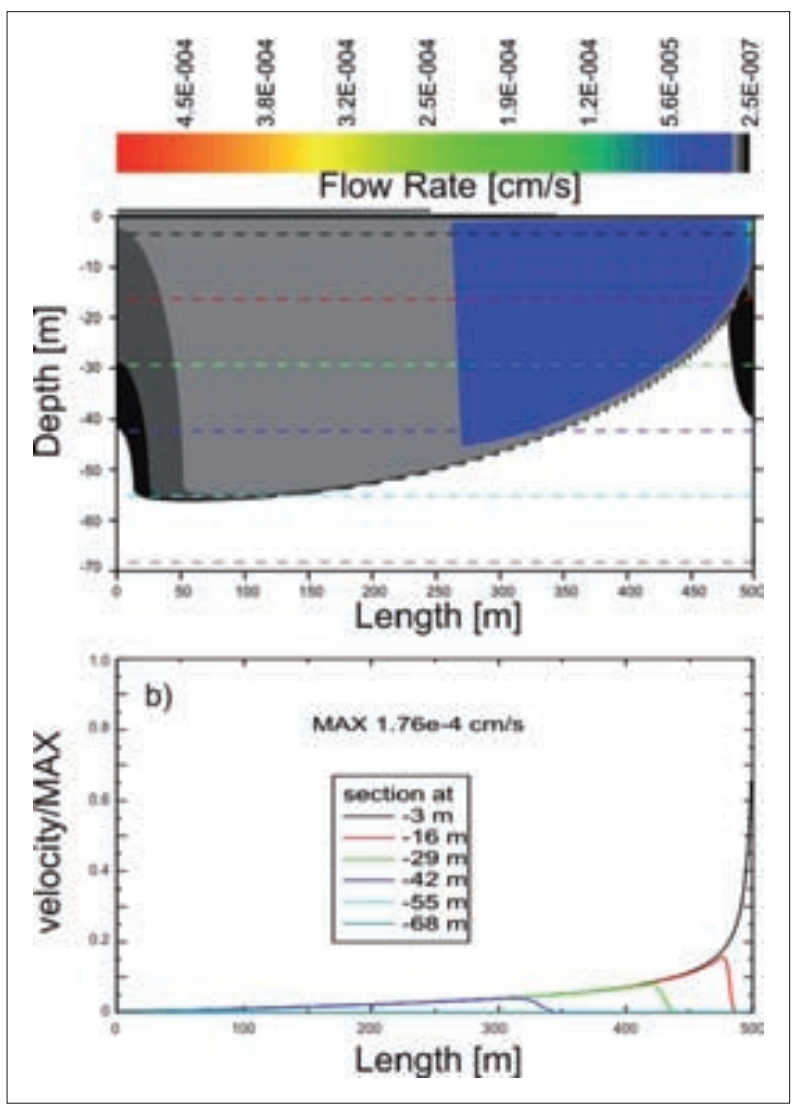

Fig. 10: Homogeneous island. a) Local distribution of flux

b) flux along horizontal sections as indicated in a).

in between their maxima but close to the region of high values of the second derivative.

Figure 13 further illustrates this qualitatively. The red region depicts the locations of the modeling domain where (grads) $)^{2}$ exhibits values $v a l \geq 10^{-2} v a l_{\text {max }} \cdot v^{\prime} l_{\text {max }}$ is the maximal value. The green region shows these locations for the second derivative and finally the black region shows the locations of significant changes of porosity. These findings agree with those of Sanford and Konikow (1989) who also found that changes in porosity are restricted to regions where waters contain between $0.5 \%$ and $3 \%$ of seawater.

It should be noted here that any mechanism, which changes the sigmoid shape of the salinity distribution to a linear profile would enhance evolution of porosity dramatically. In this case salinity gradients become constant in the entire mixing zone and their value is at least one order of magnitude higher at the maximal value of the second derivative. One could speculate that tidal pumping and fluctuations of the water table due to seasonal changes of infiltration could cause such linear mixing zones. Present observations in boreholes give some evidence for such transition zones. 


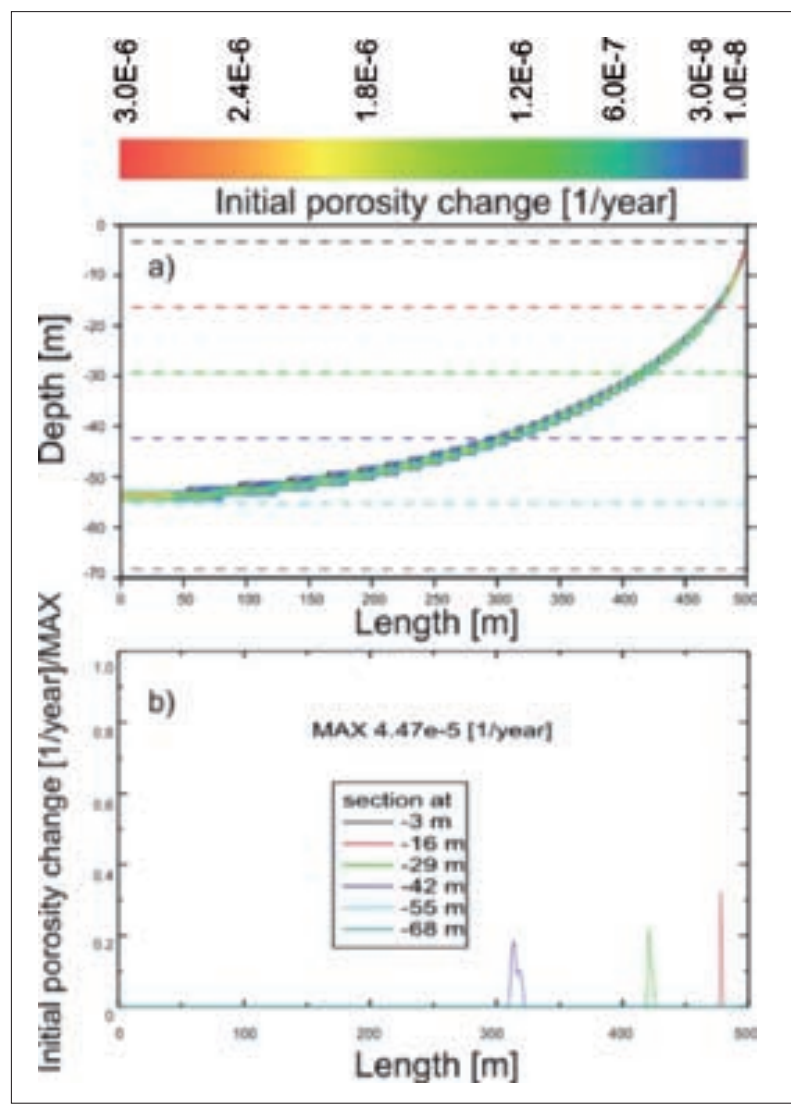

Fig. 11: Homogeneous island. a) Local distribution of initial change of porosity $\partial \phi / \partial t . b) \partial \phi / \partial t$ along horizontal sections as indicated in a).

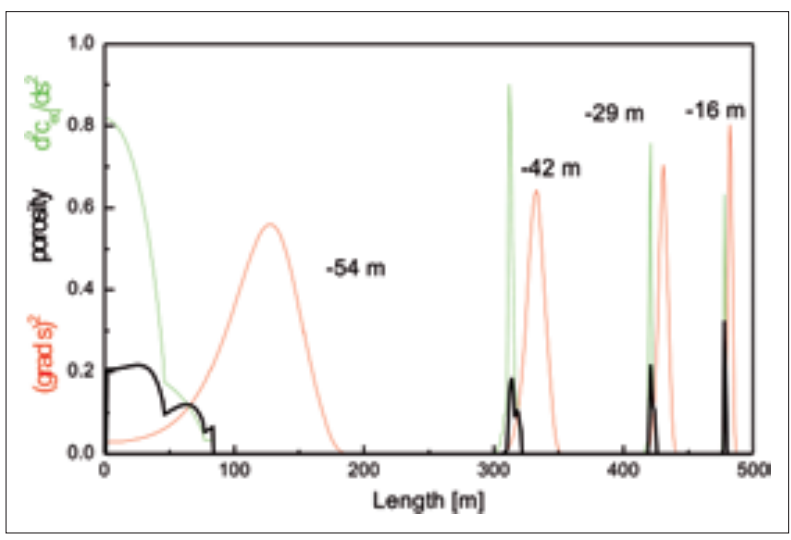

Fig. 12: Homogeneous island. (grads) ${ }^{2}$ (red), $\frac{\partial^{2} c_{e q}}{\partial s^{2}}$ (green), and) $\partial \phi / \partial t$ (black) along horizontal sections of the island. Numbers on the sets of curves give the depth of the section.

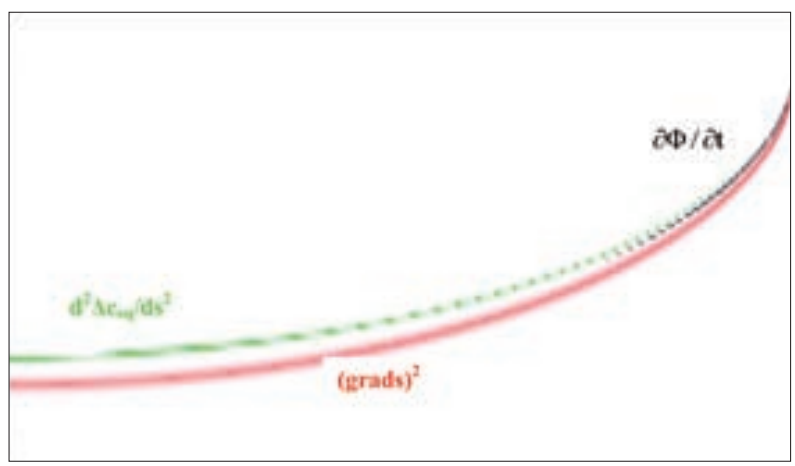

Fig. 13: Homogeneous island. Regions of (grads) $)^{2}$ (red), of (green), and change of porosity (black).

\section{INITIAL CHANGES OF POROSITY IN A HETEROGENEOUS ISLAND}

A more realistic approach to nature can be taken by employing a geo-statistical distribution of hydraulic conductivities. Figure 14 shows such a distribution generated with the software of Chiang and Kinzelbach (1998). It covers conductivities of two orders of magnitude from about $380 \mathrm{~m}$ /day (red) down to $2 \mathrm{~m}$ /day (dark blue). Most of the aquifer is occupied by values between 10-200 $\mathrm{m} /$ day. Otherwise all previous boundary conditions are unchanged. The flow field is illustrated in Figure 15. Flux is unevenly distributed, because the heterogeneous distribution of conductivities distorts the pathways of fluid elements in comparison to the regular ones in a homogeneous island. Consequently the freshwater lens in Figure 16 shows a wide transition zone (compare to Figure 7a).

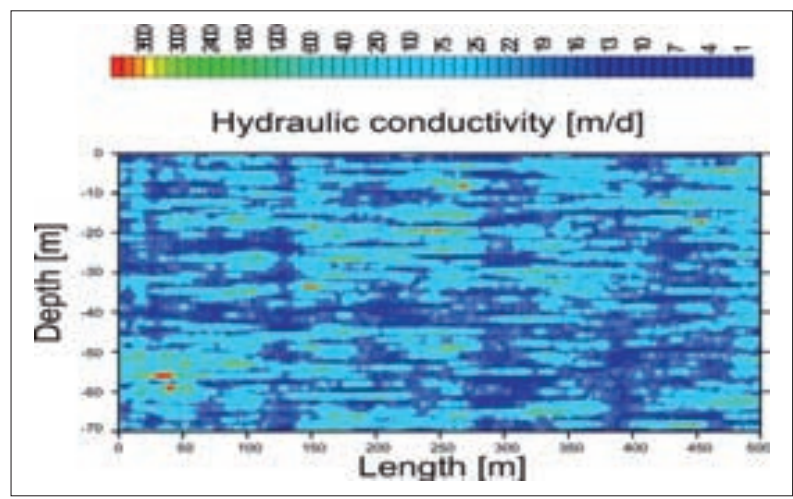

Fig. 14: Heterogeneous island. Statistical distribution of hydraulic conductivity in the modeling domain. 


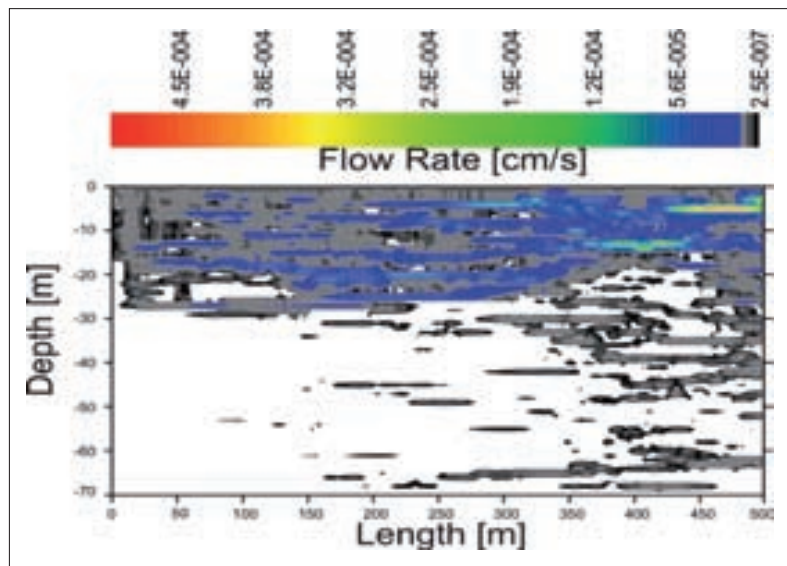

Fig. 15: Heterogeneous island. Local distribution of flux $q$.

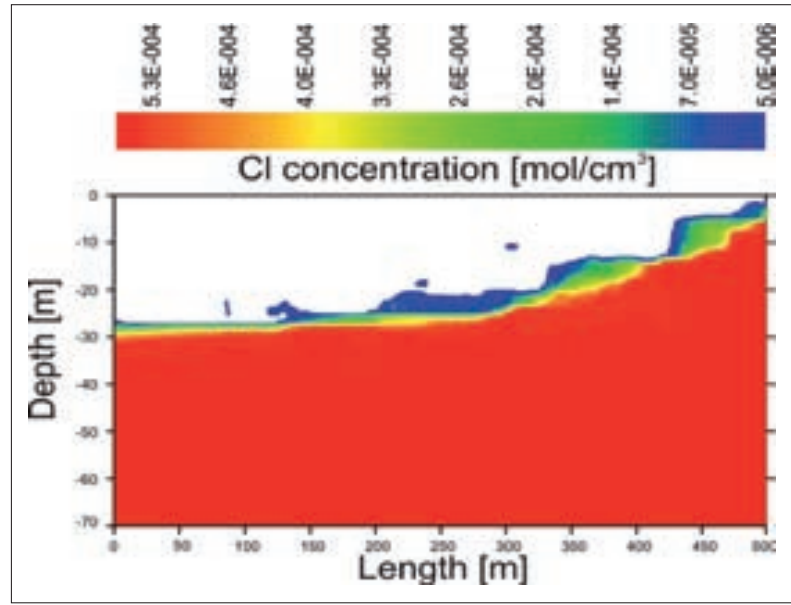

Fig. 16: Heterogeneous island. Local distribution of chlorinity $s(\vec{x})$ The white region designates the freshwater lens.

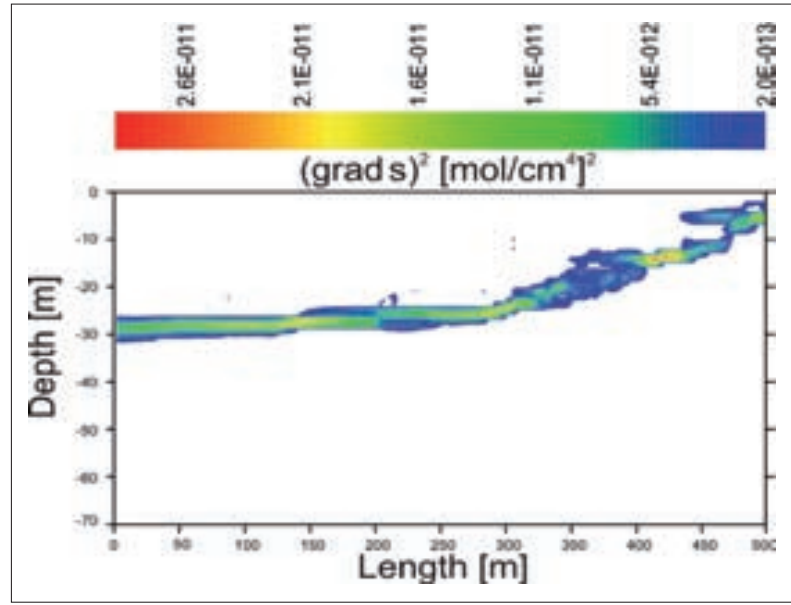

Fig. 17: Heterogeneous island. Local distribution of $|\vec{\nabla} s(\vec{x})|^{2}$.

The square of the gradient is limited to the seawater side of the transition zone, as can be visualized from Figure 17 . The region of $0-4 \%$ mixtures extends far into

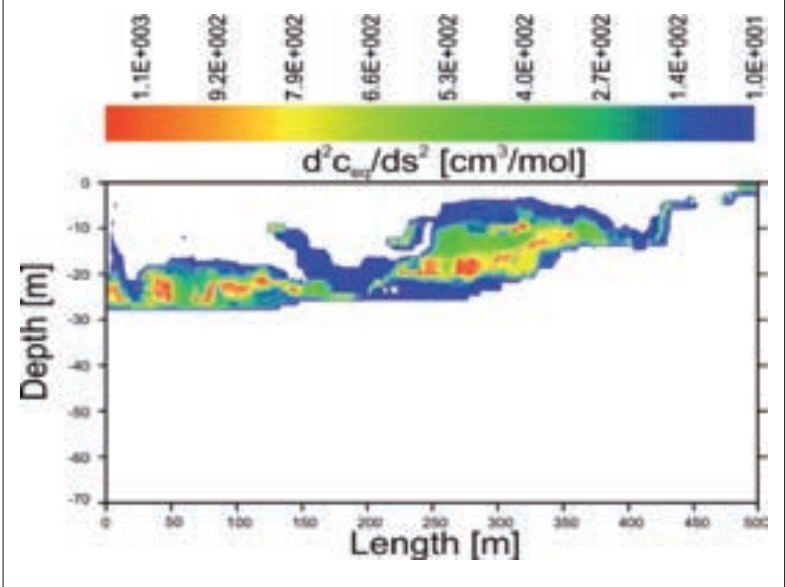

Fig. 18: Heterogeneous island. Local distribution of derivatives $\frac{\partial^{2} \Delta c_{e q}}{\partial s^{2}}$

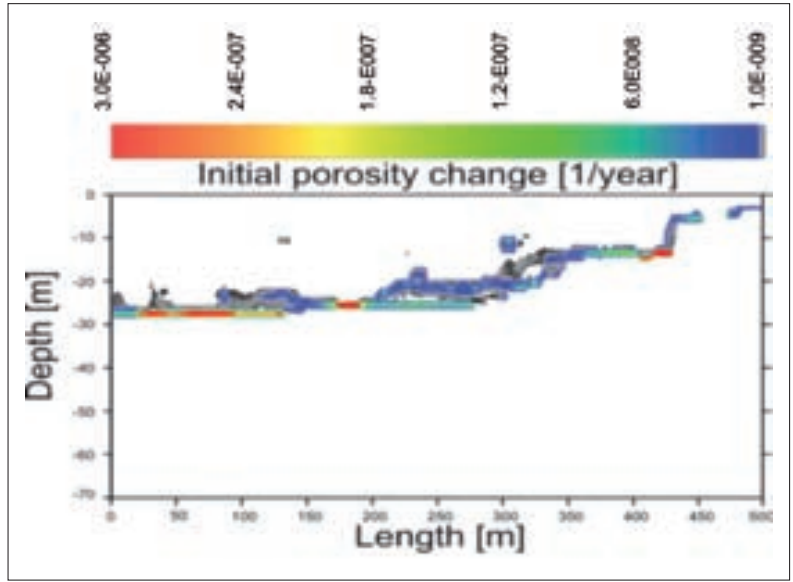

Fig. 19: Heterogeneous island. Local distribution of initial porosity change $\partial \phi / \partial t$.

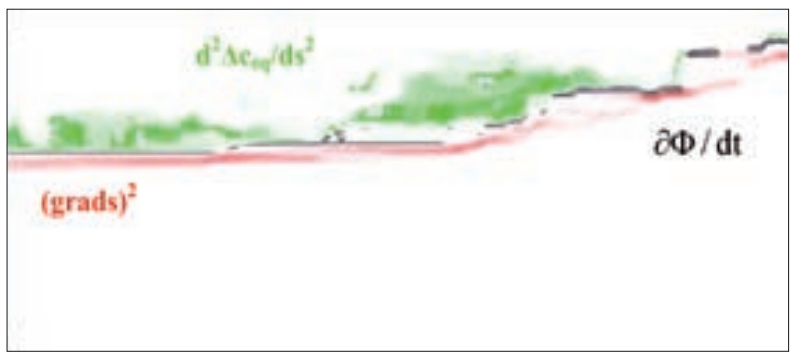

Fig. 20: Heterogeneous island. Regions of high values of (grads) (red), $\frac{\partial^{2} \Delta c_{e q}}{\partial s^{2}}$ (green), and change of porosity (black) in the modeling domain.

the freshwater lens. This can be also visualized from the second derivatives as shown in Figure 18.

Figure 19 illustrates the initial change of porosity, which exhibits high values of $3 \cdot 10^{-6}$ year-1 $^{-1}$ (red) at only a few locations close to the freshwater side of the transition 
zone. At some favorable locations (red and yellow) caves may evolve there in several 10,000 to 100,000 years.

This is further illustrated by Figure 20, which shows the regions of high values for (grads) ${ }^{2}$ (red), $\mathrm{d}^{2} \mathrm{c}_{\mathrm{eq}} / \mathrm{ds} \mathrm{s}^{2}$ (green), and $\partial \phi / \partial t$ (black) in the modeling domain. Fig- ure 21 depicts (grads) ${ }^{2}$ (red), $\mathrm{d}^{2} \mathrm{c}_{\mathrm{eq}} / \mathrm{d} \mathrm{s}^{2}$ (green), and $\partial \phi / \partial t$ (black) along selected horizontal sections.

In both figures we find that the regions of (grads) ${ }^{2}$ (red), $\mathrm{d}^{2} \mathrm{c}_{\mathrm{eq}} / \mathrm{ds}^{2}$ (green) are well separated and porosity develops in between. Due to the heterogeneity, however, the patterns become complex.

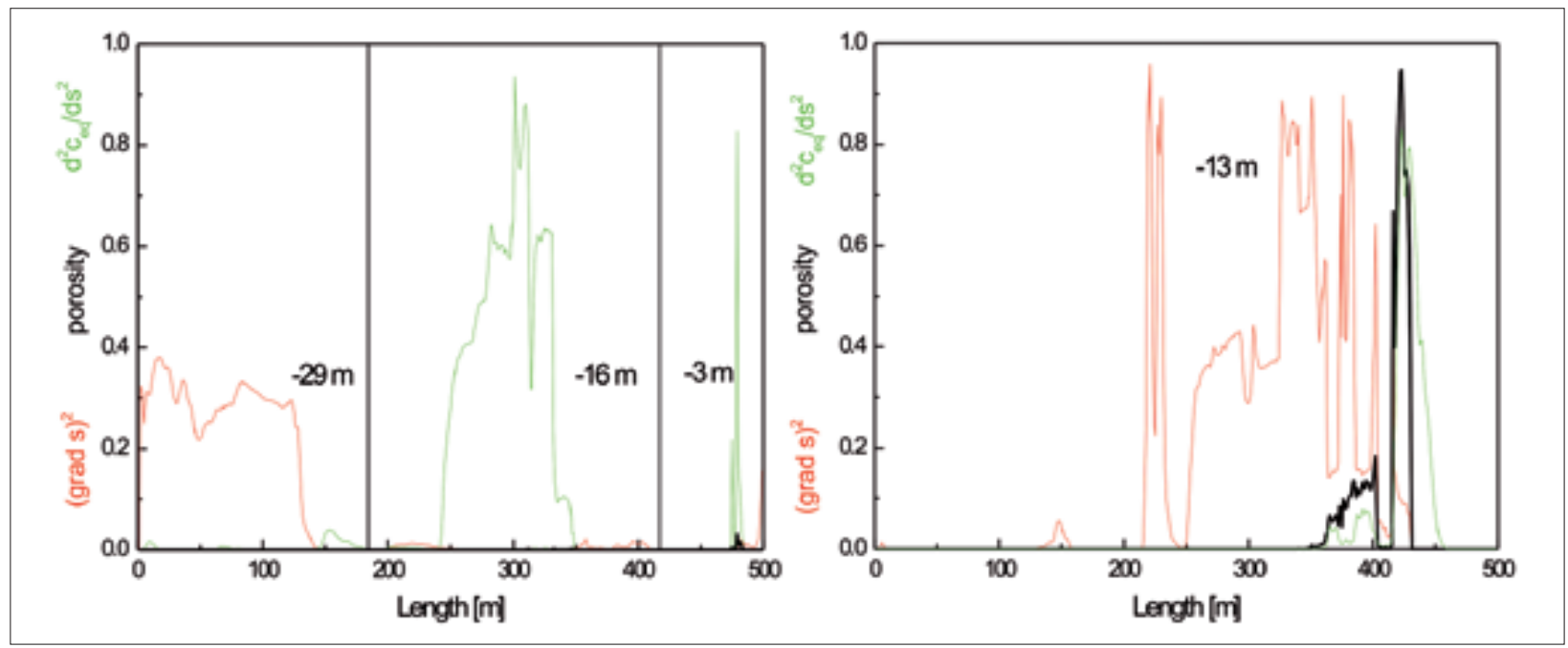

Fig. 21: a) Heterogeneous island. Distributions of (grads) $)^{2}$ (red), $\frac{\partial^{2} \Delta c_{e q}}{\partial s^{2}} \quad$ (green), and porosity change (black) along selected horizontal sections. Number on the sets of curves give the depth of the section.

\section{INITIAL CHANGES OF POROSITY IN SALTWATER TONGUES.}

When impermeable strata underlay an island sufficiently close to its surface the freshwater lens cannot extend below this layer and a saltwater tongue intrudes from the coastland inward until it reaches the impermeable layer. From thereon the freshwater lens is truncated by this layer. In this situation mixing of waters is restricted to the transition zone of the tongue and one expects high dissolution rates in this region.

Fig. 22 shows the local distribution of chlorinity and the initial change of porosity using the statistical distribution in Figure 14 for the upper permeable part. The mixing zone exhibits a structure similar to that of the heterogeneous island at the corresponding locations. Porosity changes at the outflow are low, but we find values up to $10^{-6}$ 1/year land inward at various lo-

Fig. 22: Coastal aquifer with heterogeneous conductivity down to $29 \mathrm{~m}$ as used in Fig. 14. The strata below $29 \mathrm{~m}$ are impermeable (grey). Local distribution of Cl-concentration $s(x)$ and initial porosity change $\partial \phi / \partial t$. cations and also at the contact of the tongue with the impermeable rock.

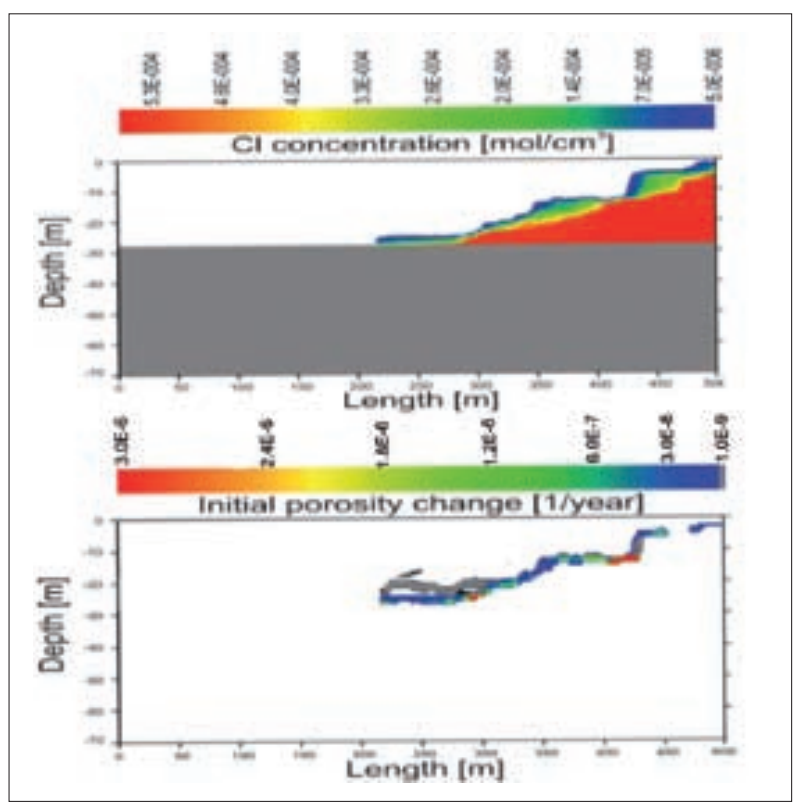




\section{CONCLUSION}

We have taken substantial steps in modeling the initial porosity changes in fresh water - saltwater mixing zones under various geological settings. We have demonstrated that the knowledge of the distribution of salinity and the amount of the flow velocity is sufficient to calculate the initial distribution of porosity changes. These are the first modeling results, which do not need scaling parameters for calibration as the models of Sanford and Konikow (1989), or more complex non-linearly coupled sets of differential transport- advection equations (Saaltink et al., 2004). We now understand that in a stationary island high porosity can develop only if high salinity gradients exist in the region of low saltwater content to up to $3 \%$. For the highly idealized scenarios of islands with homogenous hydraulic conductivity we find clear rules about the geometric distribution of porosity. These, however, are destroyed for islands with a statistical distribution of hydraulic conductivity. Each realization of a statistical distribution then will give different results, and a general standard scenario cannot be used as a tool. In heterogeneous settings porosity could occur at any place below the island and at favorable settings also flank-margin caves will arise. This explains why presence of these caves is not the rule, as it should be in homogeneous settings, where porosity develops only at the base and the outflow of the lens. In view of the restricted knowledge about the hydraulic properties and the initial porosity of the rock, which one necessarily has in carbonate platforms, detailed applied modeling at present, and most likely in the next decades will not be available.

On the other hand our findings give a firm basis for understanding the evolution of porosity on time scales of several ten to several hundred thousand years. Using an iterative procedure to implement changes of porosity and hydraulic conductivity in each time step will reveal the basic properties of processes involved in creating macro-porosity such as caves and conduits. Feed back mechanisms, which enhance dissolution in the regions of increased porosity and hydraulic conductivity could accelerate the evolution of porosity. Therefore time scales derived from the initial change in porosity represent upper limits only.

Further work into this direction is needed.

\section{ACKNOWLEDGEMENT}

We thank TOTAL S.A. for supporting this work.

\section{REFERENCES}

Chiang, W. H., Kinzelbach, W., 1998: Processing Modflow. A simulation system for modeling groundwater flow and pollution

Guo, W., Langevin, C. D., 2002: User's guide to SEAWAT: a computer program for simulation of three-dimensional variable-density ground-water flow. U. S. Geological Survey Techniques of Water-resources Investigations Book 6, USA.

Mylroye, J. E., and Carew, J., L., 2000: Speleogenesis in coastal and oceanic settings. In: Klimchouk, A., Ford, D. C., Palmer, A. and Dreybrodt, W. (Editors), Speleogenesis: Evolution of karst aquifers. National Speleological Society, Huntsville, 226-233.

Parkhurst, D. L., Apello, C. A. J., 1999 (Version 2): User's Guide to PHREEQC - a Computer Program for Speciation, Reaction-path, 1D-transport, and Inverse Geochemical Calculations, Technical Report 99-4259. U. S. Geological Survey, USA.
Phillips O. M., 1991: Flow and reactions in the permeable rocks. Cambridge University Press. Cambridge, New York, Port Chester, Melbourne, Sydney. 1991.

Romanov D. and Dreybrodt W., 2006: Evolution of porosity in the saltwater-freshwater mixing zone of coastal carbonate aquifers: An alternative modeling approach. Journal of Hydrology 329, 661-673

Saaltink, M.W., Batlle, F., Ayora, C., Carrera, J., Olivella, S., 2004: RETRASO, a code for modeling reactive transport in saturated and unsaturated porous media. Geologica Acta 2 (3), 235-251

Sanford W. E., Konikow L. F., 1989: Simulation of Calcite Dissolution and Porosity Changes in Saltwater Mixing Zones in Coastal Aquifers. Water Resources Research, v. 25, No. 4, p. 655-667. 1989.

Vacher H. L., 1988: Dupuit-Ghyben-Herzberg analysis of strip-island lenses. Geological Society of America Bulletin, v. 100 p 580-591. 1988. 